\title{
若年無業者支援における農業の導入実態と課題
}

\author{
中本 英里 ${ }^{1)}$ ・胡 柏 2 **
}

\section{The Present State and Issues of Agricultural Activities in Supporting Youth Employment}

\author{
Eri Nakamoto ${ }^{1)} \& \mathrm{Hu} \mathrm{Bai}^{2) *}$
}

This study clarifies the state of agricultural activities introduced in 160 Regional Youth Support Stations (RYSSs) across 47 prefectures using a questionnaire. The results suggest that $74 \%$ of the RYSSs have introduced agricultural activities for young unemployed people. However, the conditions キーワード：若年無業者，地域若者サポートステーション,

1.はじめに

農業の有する医療的・福祉的機能を活用した取組 は，作業療法の一部門あるいは「園芸療法」として 普及してきた経緯があり，主に医療・福祉分野にお いて有効性が検証されてきた 1 . しかし，近年では 農業分野に扮いても注目が高く, 2010 年 3 月策定の 「食料・農業・農村基本計画」以降，「食料・農業・ 農村白書」では関連する取組が継続的に取り上げら れるようにもなっている2。

農業が有する療法やリハビリ等としての側面のみ ならず，経済活動や生産財としての側面を活用した 取組は, 高齢者や障害者の就労支援の一手段, 農業 振興，農村活性化の手法としても期待されており， 2013 年度以降の農林水産省予算飞も反映されてい る. 片倉他（2007）は，農業経営に打沙障害者雇 用が，農業者にとって安価な労働力の確保や経営意 欲の向上に繋がることを示唆し，飯田他（2011） は, 社会福祉法人等による農業分野への進出が, 耕作 放棄地の活用に結びついている実態を明らかにした。 これに対して本研究では，若年無業者支援を対象 for these activities are still insufficient for meeting employment needs. A case study shows that human resources are the most important factor for developing these activities. Then, such agricultural activities could be used not only as job training but also to increase employment.

\section{農業活動，就労支援，園芸療法}

領域とする，支援現場における農業の導入は，既に 一定の蓄積があり ${ }^{3}$, 農作業の効果として，心身の 健康回復や就労意欲の向上等が認められている他, 農業活動の遂行が，地域農業に抒㺭る労働力不足の 補填あるいは耕作放棄地の削減に寄与している実態 が事例分析により実証されている（笹井他，2010）。 しかし，このような若年無業者支援に関する実証的 研究の蓄積は少ない 4 . まずは, 農業活動に焦点を 絞った支援実態の解明が必要である.

\section{2. 対象と方法}

若年無業者は「15 34 歳の非労働力人口のうち, 家事も通学もしていない者」と定義され（内閣府, 2014 : p. 39), 現在, 約 59 万人にも上ると推計され ている. 大別して, 就業希望を表明しつつも求職活 動を行っていない「非求職型」と, 就職希望を表明 していない「非希望型」に分けら机，求職活動や就 業希望を阻害する要因の多くは「病気やけが」とさ 孔ている. また，工藤他（2014：p. 27）によると, 「必ずしも急惰の帰結ではなく」, 1990 年代後半以降

\footnotetext{
1) 愛媛大学大学院農学研究科; Graduate School of Agricultural Science, Ehime University

2) 愛媛大学農学部; Faculty of Agriculture, Ehime University

* E-mail: richardh@agr.ehime-u.ac.jp 
の不景気に伴ら雇用環境の悪化や就業構造の变化等 にも由来する。様々な事象が混在して打り, 単一的 な就労支援のみならず，医療・福祉等関連機関との 連携を踏まえた支援が求められている.

国による支援は 2003 年の「若者自立・挑戦プラ ン」5策定から始まり，その一環として 2006 年に通 所型支援として「地域若者サポートステーション（以 下「サポステ」）事業」が開始された．現在，全国に 160 箇所設置され，NPO 法人等により運営されてい る。サポステでは，相談事業や職業体験事業等を通 して就労意欲の向上や職業意識の啓発が目指され, 必要に応じてハローワーク等就職斡旋機関による支 援へ移行する取組もある. 2013 年度の進路決定者数 は 1 万 9,702 人で，その内， $83.3 \%$ が就職を果たし た．農業活動は，主に職業体験事業の一つとして位 置づけられて扣り，毎年発行される支援事例集でも その実態が報告されている（日本生産性本部, 2013）.

本研究では， サポステ事業に対象を限定し，支援 現場に打ける農業活動の導入実態と課題を明らかに する. 全体の導入状況の把握についてはアンケート 調査を実施した. 調査票は 2013 年 9 月〜 11 月の間, 郵送により全国すべてのサポステに配布し，スタッ フによる回答返信方式とした ${ }^{6}$. その結果, 96 件の 回答を得た（回答率 60\%). また, 事例分析として, $\mathrm{S}$ サポステを対象に現地調査を実施した. S サポス テでは積極的な農業活動が見られる他, 利用者の進 路決定率が高く，運営法人として「若者自立支援功 労団体厚生労働大臣賞」を受賞した経歴もあること から，先駆的な事例として他の取組に示唆を与える ものがあると考光られる。

\section{3. 若年無業者支援における農業活動の導入実態}

\section{（1）アンケート結果の概要}

回答のあった 96 件のサポステのらち, 農業活動の 「導入歴がある」と回答したのは 71 件である. 活動 場所は「借用農地」（35 件）と「農家等の訪問先」 （34 件）のいずれかで多い. 作業内容は 8 割以上が 「除草」と「収穫」，6割以上が「苗の植え付け」と 「種まき」を実施して扣り，収穫後の「袋詰め」や 「販売」の実施は 2 割程度である. 実施頻度は「単発 的・不定期的」，実施期間は「1 日間」で最も多い が，「1 か月以上」も2 割程度ある。現場指導者は
「サポステスタッフ」が 40 件，「訪問・連携先農家 等」が 33 件で,「運営法人の家族」も数件ある.

得られた効果として，半数以上が「就労意欲の向 上」と「生活態度の改善」があったと回答し，「就 農」が 17 件ある. 参加者から得られた感想として, 農作業に対する楽しさや大変さの他,「心身症状の改 善」や「スタッフとの距離が縮まった」等も挙げら れている. また, 期待する効果として 6 割以上が「コ ミュニケーションスキルの向上」を挙げている.

一方，取組課題は，「現場スタッフの確保」が 16 件，「資金の確保」が 15 件，「活動場所確保」が 13 件，「農業サイドとの連携」が 10 件，「特にない」が 8 件である．農業サイドとの連携については，「サポ ステサイドから依頼する」が 44 件，「農業サイドか ら依頼を受ける」が 10 件，「連携がない」が 13 件 である。

以上より，支援現場に打ける農業活動の効果に対 する認識と期待の高さは確認されたが, 取組形態は 様々で，実施環境の整備や農業サイドとの連携が不 十分な施設が存在することも明らかとなった。

\section{(2) 連携のメリットと課題}

農業の医療的・福祉的活動に颃ける課題として, 医療・福祉サイドと農業サイドとの連携が挙げられ る 7 . 以下ではアンケート結果を基に, サポステと 農業サイドとの連携の特徵や利点, 課題に焦点を当 て，実態を具体的に把握していく.

関連項目をクロス集計した結果，活動場所が「借 用農地」の場合では「連携なし」が多く，約 8 割が 現場指導者を「サポステスタッフ」とし，「農家等の 訪問先」では「サポステから依頼する」が多く，約 7 割が現場指導者を「訪問・連携先農家等」として いたことから 8 ，「農家等の訪問先」を活動場所とす るサポステの方が農業サイドとの積極的な連携が図 られる傾向があると考えられる. 連携のメリットと して，「農家等の訪問先」の方が得られた効果で「就 農」が多かったこと，指導者が「訪問・連携先農家 等」の方が作業内容で「農産物販売」と「袋詰め」 が多かったこと，「借用農地」の方が取組課題で「現 場スタッフの確保」が多かったことから，就農への 円滑化，作業内容の多様化，農業サイドからの人的 資源の支援に対する期待が高いことが考えられる. しかし，活動場所が「農家等の訪問先」の方が，取 
組課題で「農業サイドとの連携」と「利用者の希望」 が多かったことから，現状では，連携時のノウハウ が不十分であると考觉られる。

次節では，農業サイドとの円滑な連携が図られて いる $\mathrm{S}$ サポステへの調査を基に，サポステに拈ける 農業活動の具体的内容を明らかにし, 先進的取組か ら示唆される今後の展開の可能性についてみる.

\section{Sサポステにおける農業活動}

\section{(1) 運営団体の概要}

$\mathrm{S}$ サポステの開所は 2007 年 4 月である. 20 年前 から若年層の支援に携わってきた NPO 法人により 運営されている. 2013 年度の登録者数は 266 名, ら ち進路決定者数は 158 名で, 年々増加傾向にある.

運営団体の設立は, 高校教師であった前理事長が, 不登校や高校中退者等の受け血の少なさを痛感し て，学校を退職し，若者層の支援を開始したことが 発端である. 1989 年にカウンセリングの事業所を立 ち上げ，教育支援，障害者就労支援事業を併設し， 2000 年に NPO 法人の設立に至った.

図 1 に現在の事業の仕組を示す。事業内容は相談 事業，教育事業，就労支援事業に大別される．障害 者支援事業は 2006 年に NPO 法人として独立させ, 就労継続支援 $\mathrm{A}$ 型事業所を開設している. 教育事業 と就労支援事業には自主事業と委託事業があり，サ ポステ事業は委託事業として 2014 年まで毎年受託 している. 自主事業にはカウンセリング, 学習支援,
ジョブトレーニング等があり，利用料は全て有料で あるが，初回から１か月間は無料にするなど，利用 者の負担を軽減する等の工夫がなされている. また, 具体的な就労体験・訓練の場の整備として, 2005 年 に「NPO カフェ」をフランチャイズ加盟店としてオ ープンし，2011 年に地産地消の店，2012 年には自 主農園を順次開設している.

\section{(2) 経営状況と運営体制}

2012 年度の事業収入は約 1 億円で，らち委託事業 収入が $52 \%$, 自主事業収入が $30 \%$ ，その他に NPO 会費収入や寄付金収入が含まれている。事業費は人 件費が $60 \%$ ，商品や材料の仕入れ高が $15 \%$ ，その 他に事務所や各運営店舗の賃借料 $5 \%$ 等が含まれて いる．事業収支のみでは黒字だが，その他管理費等 を含めると赤字になる年もある.

運営団体のスタッフは35名, らち 9 名がサポス テ事業に従事している. 委託事業専従により期限付 きで雇用されている者もいるが，各種保険等を含め 待遇面で正規社員との違いはない，採用に当たって は心理士等の資格の有無や経験は特に問わず，支援 者としての熱意や責任感を重視して抢り，ボランテ ィアは採用していない.

\section{（3）農業活動の実施方法}

$\mathrm{S}$ サポステにおける農業活動は，「農家等の訪問 先」と「借用農地」を活動場所とし, 以下で述べる 「ジョブトレーニング事業」を活用している，そのた め, サポステスタッフの中には農業専従の者は扮ら

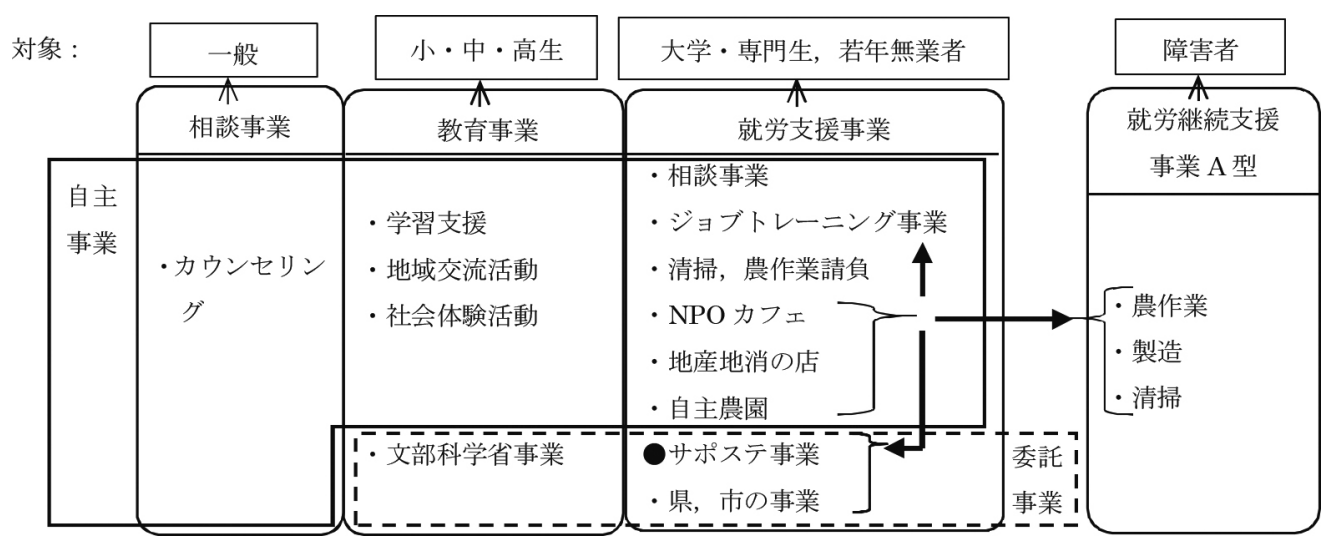

図 1. S サポステを運営する NPO 法人の事業概要

資料：聞き取り調査及び $\mathrm{S}$ サポステからの提供資料を基に作成.

1）○は $\mathrm{S}$ サポステの位置，太字矢印は「具体的な就労体験・訓練の場」が活用される事業を指している. 
ず，基本的には「ジョブトレーニング事業」専従ス タッフとの連携により実施されている.

「ジョブトレーニング事業」とは，厚生労働省の 「緊急雇用創出事業臨時特例交付金」9 を財源とする 県の「緊急雇用創出事業」を活用した委託事業の一 つで，2010 年から 2014 年現在まで継続的に受託し ている，農業分野の他に清掃，製造，木工，喫茶が ある. 指導役として業務にあたるスタッフは「ジョ ブコーチ」と呼ばれる。「求職者からコーチを募る」 といら同法人独自の仕組みによりハローワークを通 じて採用され，約 1 か月間の研修を経て指導業務に あたる，現在，農業部門には 4 名のスタッフが採用 されており, 利用者の送迎, 栽培, 加工, 袋詰め, 販売活動, 作業計画作成等を主な業務としている. スタッフの中には農業経験者と末経験者が扣り，ス タッフ間での情報共有および近隣農家からの指導に より，活動内容の充実化が図られている.

$\mathrm{S}$ サポステに打ける支援の基本的な流れは，1 か 月目に主に心理カウンセリングや各種検査, 保護者 を加えた面談が実施される．2 か月目以降にジョブ トレーニング等を活用し，希望や状況に応じて農業 活動を含む各部門の作業が実施される。その後は, 就労等への移行措置が図られる。農業活動は他の活
動と比較して利用者からの人気が高く，「一歩を踏み 出したい若年無業者には参加に対する心理的抵抗が 少ない」「コミュニケーションが自然な形で取りや すい」と考光られて扮り，支援の導入段階，実質的 な活動段階の双方で取り入れられている.

\section{（4）活動効果と課題}

表 1 は農業活動に参加した利用者への支援経過と 活動参加への感想を示している．Ａ氏とＢ氏は一般 (外部) 就労, C 氏と D 氏は関連法人が運営する就 労継続支援 $\mathrm{A}$ 型事業所での福祉的就労を果たしてい る. 支援期間, 経過, 目標, 抱えている課題, 支援 の方向性等はそれぞれ異なり, 農業活動についても 同様のことが言える. 例えば,「就農」が最終目標で あった A 氏にとって，自主農園での活動や農家での 短期アルバイトは就職に向けての具体的な訓練とな り，不足していた体力を補ら機会にもなった．B氏 は支援終結後に復職を果たしたが，休職に至った経 緯では希望職種と従事していた業務内容とのミスマ ッチがあり，「気持ちの整理」や「決断力の養成」が 支援全体の課題であった。農業活動に対する感想で は，定期的な農業活動への参加により規則的な生活 が取り戻され，充実感や達成感が得られたと述べて いる. 復職への移行段階で必要な心身の健康回復や

表 1. S サポステ利用期間中に農業活動に参加した利用者の経過と農業活動に対する感想

\begin{tabular}{|c|c|c|c|c|}
\hline $\begin{array}{l}\text { 利用者/ } \\
\text { 支援期間 }\end{array}$ & 経過・農業活動の内容 & 目標・課題 & 結果 & 農業活動の感想 \\
\hline $\begin{array}{l}\text { A 氏 } \\
\text { /約 } 9 \text { か月 }\end{array}$ & 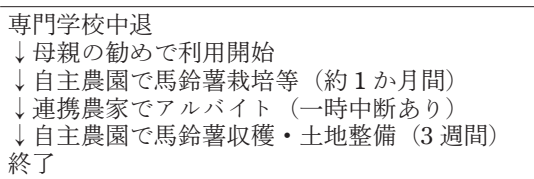 & $\begin{array}{l}\text { ・就農希望 } \\
\text { ・運転免許取得 } \\
\text { ・体力づくり }\end{array}$ & $\begin{array}{l}\text { ・運転免許取得 } \\
\text { •農業関連会社に } \\
\text { 正社員として } \\
\text { 就職 }\end{array}$ & $\begin{array}{l}\text { ・直接土に触れる楽しさ } \\
\text { ・持久力 } \\
\text { ・コミュニケーション能力の } \\
\text { 向上 } \\
\text { ・農業への関心 }\end{array}$ \\
\hline $\begin{array}{l}\text { B 氏 } \\
\text { /約 } 3 \text { か月 }\end{array}$ & 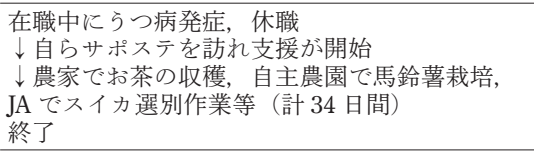 & $\begin{array}{l}\cdot \text { 復職 } \\
\text { ・体力゙くり } \\
\text { ·気持ちの整理 } \\
\text { ・決断力の強化 }\end{array}$ & $\begin{array}{l}\text { ・復職 (パートタ } \\
\text { イムから) }\end{array}$ & $\begin{array}{l}\text { • 充実感 } \\
\text { • 垟成感 }\end{array}$ \\
\hline $\begin{array}{l}\mathrm{C} \text { 氏 } \\
\text { /約 } 1 \text { 年半 }\end{array}$ & $\begin{array}{l}\text { 在職中に統合失調症を発症, 退職 } \\
\downarrow \text { 障害者手帳取得, サポステ䦌始 } \\
\downarrow \text { 農業活動に参加（自主農園開設前より） } \\
\text { 利用者のリーダー的存在となる } \\
\text { 就労継続支援 A 型へ支援移行（関連法人） }\end{array}$ & $\begin{array}{l}\text { ・障害者雇用枠での } \\
\text { 就労 }\end{array}$ & $\begin{array}{l}\text { •関連法人と雇用 } \\
\text { 契約 }\end{array}$ & $\begin{array}{l}\text { ・顔なじみの仲間との共同作 } \\
\text { 羓が良かった }\end{array}$ \\
\hline $\begin{array}{l}\mathrm{D} \text { 氏 } \\
\text { /約 } 3 \text { 年 }\end{array}$ & $\begin{array}{l}\text { 大学在学中に統合失調症を発症, 休学 } \\
\downarrow \text { 法人内の教育事業支援を受け, 大学卒業 } \\
\downarrow \text { サホステ利用開始, 料理, 清掃, } \\
\text { 除草ボランティア, 解体作業を経験 (一時中断) } \\
\downarrow \text { 障害者手帳取得, 農業活動にも参加 } \\
\text { 就労継続支援 A 型へ支援移行（関連法人) }\end{array}$ & $\begin{array}{l}\text { ・障害者雇用枠での } \\
\text { 就労 }\end{array}$ & $\begin{array}{l}\text { •関連法人と雇用 } \\
\text { 契約 }\end{array}$ & $\begin{array}{l}\text { ・達成感 } \\
\text { ・気心が知れた仲間と作業が } \\
\text { でき安心感があった }\end{array}$ \\
\hline
\end{tabular}

資料 : S サポステスタッフ及び各利用者へのインタビュ一調査を基に作成. 
活動意欲全般の向上が見られたと言える.

また，C氏とD 氏は，農業活動に拈ける「仲間と の共同作業」にプラスの印象を持っていたとの感想 を述べた．自閉的傾向があり，他者との関わりが困 難である両者にとって，農業活動は無理なく参加で きる集団活動として位置づけられていたと見て取れ， 今後も実施可能な活動の一つとなっている．両氏は 今後, 一般就労を目指している.

以上より，農業活動による効果は，各人が抱えて いる課題によって微妙に異なり，多様な場面で発揮 されている. その理由として，まず，上述の通り， 利用者が参加する際の心理的抵抗が少ないことが挙 げられる。また， S サポステスタッフによれば，職 場体験に打ける農業活動では，製造業と比較して受 け入れ先から時間的制約が求められにくいといった 特徵も挙げられている. このよらな特徵を有する点 も, 多様な場面で適用可能な理由として考えられる.

しかし, 就労, 復職等の決定的な成果は, 決して 農業活動のみによるものではない. 繰り返し行われ た面談やスタッフ間の連携，スタッフの技量，家族 の理解が支援過程の根底にあり, さらに農業活動に 必要な環境が整備されていたことが，就労支援とし ての効果獲得に慗がったと見るべきであろら.

$\mathrm{S}$ サポステ運営法人に打憹業関連事業は, 当 初は小規模で実施され, 農家での体験活動と, 地域 の農家から無償で借り受けた約 1 a の農地（遊休農 地）での栽培活動のみであったが，2010年に「ジョ ブトレーニング事業」が導入された事を機に，農業 活動の環境は, 以下のように急速に整備されてきた.

先ず，「農家等の訪問先」の確保である. 2010 年 4 月時点では受け入れ先農家は 2 件であったが, 2011 年 3 月には 17 にまで拡大し，2014 年 5 月の調査時 点では 20 以上となった。 また，専任コーチが知人農 家を通じてJA に作業委託を依頼し，JAの出荷・集 荷作業や高齢農家の荷卸しの手伝い等も活動に組み 込まれるようになった. JA 担当者は「定期的に仕事 は依頼できないが，農家の高齢化が進むこの地域で は力仕事は人手不足で, 必要な時にスポット的な労 働力となってくれて大変助かっている」と話して未。 り，同取組は地域貢献にも慗がりつつある。連携先 の農家やJA からは 1 件につき 5 千円から 1 万円程 度の報酬が支払われ，今後の活動資金としている。
次に，「借用農地」の確保として，自主農園の開設 が挙げられる. 自主農園は市内中心部から車で 20 分 程離れた山間部にある. 地域の農家やJA の協力，市 農業委員会の承認を経て休耕地 $1,104 \mathrm{~m}^{2}$ の賃貸契約 が成立し， 2012 年 2 月中旬より開墾が開始された. 同年 3 月に約 5 a に馬鈴薯が植え付けられ，6 月下旬 に約 $1 \mathrm{t}$ を収穫した. 同法人が運営する地産地消の 店で販売された他，10 kg は市内の小中学校へ給食 用として寄贈した。生産規模は徐々に拡大し，翌 2013 年は $10 \mathrm{a}$ で約 $2 \mathrm{t}, 2014$ 年は $20 \mathrm{a}$ で約 $4 \mathrm{t}$ を収 穫した。馬鈴薯の他にニンジン，ダイコン，ブロッ コリ一等も栽培し, 加工品も生産している. 収穫物 全体の売上高は 2012 年で約 59 万円， 2013 年で約 113 万円に達して扣り, 自主事業収入の一部となっ ている.

「ジョブトレーニング事業」に農業分野を設定した 理由は二つあり，一つは就労支援としての有効性に 対する期待であり，もら一つは，「地域農業の活力創 出」のためである. 小規模ながらも農業活動を実施 していく過程で, 遊休農地の活用や農業分野に打忷 る若い労働力に対する需要の高まりを実感し, 就労 支援活動を通した農業振興への貢献が期待され，導 入に至った.

以上のように, 農業関連事業は「ジョブトレーニ ング事業」の導入に伴い具現化に至り, 地域農業へ の貢献を意識した取組が，結果として農業サイドと の有機的な連携を実現させ，農の持つ就労支援とし ての効果を発揮させていると言える. その環境整備 にあたっては,「ジョブコーチ」の果たす役割は大き い. S サポステ運営法人では, 行政への積極的な働 きかけによって人材を確保し, さらに, 組織内連携 により，農業活動に打けるサポステスタッフの負担 を軽減させ，支援活動と農業活動の充実化が図られ ている、しかし，全てのサポステでこれが実現され るとは言い難い. 農業の有する医療的・福祉的側面 と経済的側面とを上手く融合させた支援を遂行させ るためには，両者の中間点に位置するコーディネー ターの確保とその育成は必要不可欠であり, 今後は, その具体的方策の検討が必要であると考える.

\section{(5) 今後の課題}

サポステ利用者の中には諸々の理由により一般就 労への移行が困難で, 且つ福祉的就労枠に該当しに 
くい若者や，支援が終結し就労等を果たした場合で も一定期間就業した後に再び離職し，サポステ利用 者となる者も少なくない， $\mathrm{S}$ サポステでは 6 か月以 内の離職率は平均で $20 \%$ 程度と把握されている。 こ のよらな状況に鑑み， S サポステ運営法人では，現 在,「外部就労」が極めて難しいと考兄られる対象者 の受け㿼として，農業を活用した雇用の場が一定の 役割を果たしている。自主農園で野菜を生産し地産 地消の店で販売する過程で，あるいは高齢農家やJA からの作業請負を通して想定され得る様々な活動を, 利用者の訓練や体験と並行させて実際の労働活動と する仕組みである，同活動をより実効性の高い事業 へと結び付けるための努力として，2012 年にエコフ ァーマーの認定を受け, 自主農園の拡大, 地域農家 との連携による自社加工製品の販売等を試みている. 今後は新たに農業法人を設立する意向もある.

\section{5. おわりに}

若年無業者支援に扔ける支援対象拡充の必要性 は，多くの支援現場で認識されて打り，2014 年度よ りサポステ事業の中にもフォローアップを目的とし た「サポステ卒業者ステップアップ事業」が組み込 まれるようになった，職業的自立に際して他者によ る何らかの援助を必要とする若者への対応について は，一概に一般就労が目指すべきゴールとは言えず, 訓練や体験を経て就労を実現させ，自立を体現させ ることが必要である。その環境整備として「中間的 就労の場」を各地域の状況に即した労働市場の中で 確立させることが方法論として挙げられている（宮 本, 2012 ; 労働政策研究・研修機構, 2011).

支援の場を実際の就労の場として運営させるメリ ットは, 法人の存続や事業の継続可能性にも影響す ると考兄られ，単年度の委託事業に財源を依存する 不安定な財務状況を打開する上でも「自主事業」の 新たな展開は重要であると言光る。今後求めら机る 若年無業者問題の解決策の一つとしても, 農業活動 の活用は有効であると考光られる.

\section{注}

1 特に精神疾患者に有効であるとされて物り, 日本作業療法士 協会（2012）によれば, 66\%の医療機関で園芸活動が導入さ
れている。

2 平成 23 年度版はひきこもり者の社会復帰, 24 年度版は園芸 療法士の取組, 25 年度版はニート等を対象とした農業研修の 事例を掲載している.

3 民間の支援機関では政策的支援整備以前から導入されている (プラットフォームプロジェクト，2003）

4 株式会社エヌ・ティ・ティ・データ経営研究所 (2013 : p. 30）の報告では, 農業の福祉的取組への注目が高齢者領域に 偏っていること, 今後は一般勤労世代に注目が必要と指摘さ れている.

5 経済産業省, 厚生労働省, 文部科学省, 内閣府による施策の 一つである. 2004 年に合宿型支援の「若者自立塾」事業が創 設されたが，事業仕分けにより 2010 年に廃止された。

6 「導入歴の有無」以外の項目は複数回答可とした.

7 片倉他（2007）は「取組継続条件」，飯田他（2011）は「農 地有効活用」の条件として位置づけている.

$8 \chi^{2}$ 検定の結果,「サポステから依頼」,「連携なし」で活動場 所の類型間に $5 \%$ の有意差が認められた.

9 詳細は厚生労働省ホームページ「雇用創出の基金による事 業」を参照されたい。

\section{引用文献}

飯田恭子・香月敏孝・吉田行郷 - 小林茂典 - 出田安利・松島浩 道（2011）「福祉施設に打ける農業分野の障害者就労の実 態と課題」『2011 年度日本農業経済学会論文集』, 64-71.

片倉和人・山下 仁・工藤清光（2007）「農業経営に打ける障 害者雇用のマネジメント」『農林業問題研究』43(1), 78-83.

株式会社エヌ・ティ・ティ・データ経営研究所 (2013)『平成 24 年度農林水産省委託調査一農作業と健康についてのエビ デンス把握手法等調査報告書』.

工藤 啓・西田亮介（2014）『無業社会一働くことができない 若者たちの未来』朝日新聞出版.

笹井美希・川手督也（2010）「日本に打けるグリーン・ケアの 可能性と課題」『2010 年度日本農業経済学会論文集』, 220 227.

内閣府（2014）『平成 26 年版子ども・若者白書』.

日本作業療法士協会（2012）『作業療法白書 2010』.

日本生産性本部（2013）『平成 24 年度版地域若者サポートステ ーション事業事例集』.

プラットフォームプロジェクト（2003）『全国ひきこもり・不 登校援助団体レポート, 合宿型施設編』ポケット出版.

宮本みち子（2012）『若者が無縁化する一仕事・福祉・コミュ ニティでつなぐ』筑摩書房.

労働政策研究・研修機構（2011）「「若者統合型社会的企業」の 可能性と課題」( http://www.jil.go.jp/institute/reports/ 2011/0129.htm）［2015 年 3 月 3 日参照］. 